\title{
Diseases of Cocoa
}

C. A. Thorold

The economics of a number of countries in Africa and Latin America are vitally dependent on the cocoa industry, and the price of cocoa in the world market. This book discusses the main diseases that can affect cocoa in various geographical regions, and assesses the economic importance of each one. It will be useful to many people in the cocoa-growing industry at large - production and processing managers, their technical advisers, research workers, and administrators - as well as to students of tropical agriculture. $£ 11$

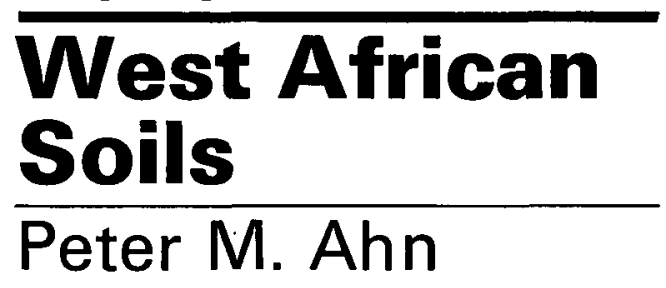

This paper-covered edition replaces Volume I of West African Agriculture. All aspects of soil science in West Africa are dealt with, including the suitability of the various soils for crop growth and methods of improving fertility. Third edition illustrated paper covers $£ 3$

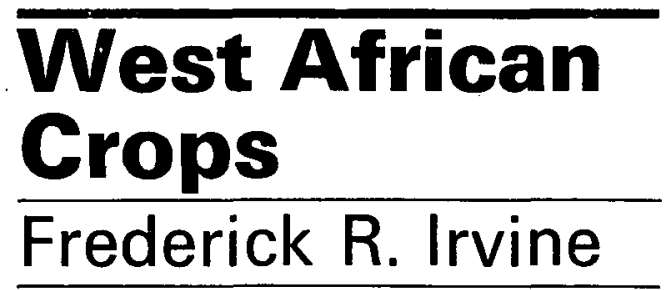

This edition replaces Volume II of West African Agriculture. It is concerned with the different varieties of crops in West Africa, the best methods for their cultivation, and ways of combating plant disease. Third edition illustrated paper covers $£ 3$

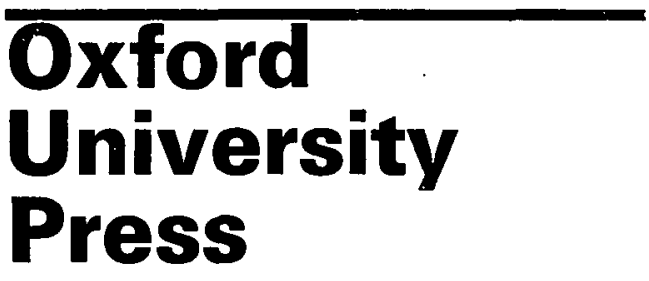




\section{EXPERIMENTAL AGRICULTURE}

Volume 11

Number 2

April 1975

\section{CONTENTS}

J. R. Stow: Effects of Humidity on Losses of Bulb Onions (Allium cepa) Stored at High Temperature

H. M. Shelton and L. R. Humphreys: Undersowing Rice (Oryza sativa) with Stylosanthes guranensis. I. Plant Density

H. M. Shelton and L. R. Humphreys: Undersowing Rice (Orysa sativa) with Stylosanthes guranensis. II. Delayed Sowing Time and Crop Variety

H. M. Shelton and L. R. Humphreys: Undersowing Rice (Orysa sativa) with Stylosanthes guranensis. III. Nitrogen supply

G. B. Masefield: A Preliminary Trial of the Pearl Lupin in England

D. J. Andrews: Sorghum Grain Hybrids in Nigeria

R. A. Sobulo, A. A. Fayemi and A. Agboola: Nutrient Requirements of Tomatoes (Lycopersicon esculentum) in S.W. Nigeria. I. Effects of $\mathrm{N}, \mathrm{P}$ and $\mathrm{K}$ on Yields

R. A. Sobulo, A. A. Fayemi and A. A. Agboola: Nutrient Requirements of Tomatoes (Lycopersicon esculentum) in S.W. Nigeria. II. Foliar Analysis for Assessing N, P and K Requirements

S. H. Salih and M. O. Khidir: Correlations, Path Analyses and Selection Indices for Castorbean (Ricinus communis L.)

A. H. El Nadi: Water Relations of Beans. III. Pod and Seed Yield of Haricot Beans under Different Irrigation in the Sudan

Book Reviews:

Biological Control of Plant Pathogens: K. F. Baker and R. J. Cook

Biological Control by Natural Enemies: P. DeBach

$£ 4.00$ net (US $\$ 12.00$ in USA and Canada)

1975 subscription $£ 11.50$ net (US $\$ 34.50$ in USA and Canada)

\section{CAMBRIDGE UNIVERSITY PRESS}

Bentley House, 200 Euston Road, London NW1 2DB 32 East 57th Street, New York, N.Y.10022 


\begin{tabular}{|l|} 
LI-COR Light Measuring \\
Instrumentation \\
Measure: \\
Photosynthetic active radiation in air \\
and water.
\end{tabular}

(iii) 


\section{THE \\ JOUR:NAL OF \\ AGRICULTURAL SCIENCE \\ EDITED BY}

Prof. J. W. L. BEAMENT, SC.D., F.R.S., Department of Applied Biology, Cambridge

G. D. H. BELL, C.B.E., PH.D., F.R.s. Plant Breeding Institute, Cambridge

K. L. BLAXTER, PH.D., N.D.A. (HONS.), D.SC., F.R.S.E., F.R.S.,

Rowett Research Institute, Bucksburn, Aberdeen

G. W. COOKE, PH.D., F.R.I.C., F.R.S., Rothamsted Experimental Station, Harpenden

Prof. Sir J. B. HUTCHINSON, C.M.G., SC.D., F.R.S., Emeritus Professor of Agriculture, Department of Applied Biology, Cambridge

J. L. LINZELL, B.SC., PH.D., M.R.C.v.S., Agricultural Research Council, Institute of Animal Physiology, Babraham, Cambridge

Prof. J. B. OWEN, B.SC., PH.D., M.A., School of Agriculture, Aberdeen

H. L. PENMAN, O.B.E., PH.D., F.R.S., Rothamsted Experimental Station, Harpenden

W. J. RIDGMAN, M.A., Department of Applied Biology, Cambridge

H. H. ROGERS, B.SC., DIP.AG.SCI., Plant Breeding Institute, Cambridge

L. E. A. ROWSON, O.B.E., M.R.C.V.S., F.R.S., Agricultural Research Council, Unit of Reproductive Physiology and Biochemistry, Animal Research Station, Cambridge

Prof. E. W. RUSSELL, C.M.G., PH.D., F.INST.P., Department of Soil Science, University of Reading

F. YATES, C.B.E., SC.D., F.R.S., Rothamsted Experimental Station, Harpenden

VOLUME LXXXIV

CAMBRIDGE

AT THE UNIVERSITY PRESS

1975 
PUBLISHED BY

THE SYNDICS OF THE CAMBRIDGE UNIVERSITY PRESS

Bentley House, 200 Euston Road, London, NW1 2DB

32 East 57th Street, New York, N.Y.10022

(C) Cambridge University Press, 1975

Printed in Great Britain at the University Printing House, Cambridge 


\section{Contents}

Part 1 (February 1975)

PAGE

Chetal, Urmila, Mehra, Usha R., Nath, K. and Ranjhan, S. K. On the variation of urinary creatinine in buffalo calves and the effect of dietary protein intake on urinary creatinine, creatinine-nitrogen ratio and creatinine coefficient

Morgan, D. J., Cole, D. J. A. and Lewis, D. Energy values in pig nutrition. I. The relationship between digestible energy, metabolizable energy and total digestible nutrient values of a range of feedstuffs

Morgan, D. J., Cole, D. J. A. and LewIs, D. Energy values in pig nutrition. II. The prediction of energy values from dietary chemical analysis

Fisher, L. J., Donnelly, P. E., Hutron, J. B. and Duganzich, D. M. Relationships between levels of feeding and certain blood metabolites in dairy cows in mid lactation

Nolan, J. V., Norton, B. W., Murray, R. M., Ball, F. M., Roseby, F. B., Rohan-Jones, W., HILL, M. K. and LENG, R. A. Body weight and wool production in grazing sheep given access to a supplement of urea and molasses : intake of supplement/response relationships

TALHA, M. and Osman, F. Effect of soil water stress on water economy and oil composition in sunflower (Helianthus annuus L.).

Smith, Mrranda E. and Jenkinson, D. McEwax. The effect of age, sex and season on sebum output of Ayrshire calves

Voldeng, H. D. and Blackman, G. E. Interactions between genotype and density on the yield components of Zea Mays. II. Grain production

FARAH, S. M. Effects of plant density and fertilization on the yield and quality of flue-cured tobacco in the Kenana area of the Sudan

BURHAN, H. O. and SAID, M. B. Residual effects of N, P and K applied to cotton on following crops of sorghum, dolichos and wheat in the Sudan Gezira

Heathсоте, G. D. and Byford, W. J. Surveys of sugar-beet seed crops, mangold clamps and seeds in England for aphids and viruses, 1963-73 .

Wood, D. W. and ScoTt, R. K. Sowing sugar beet in autumn in England .

Wanman, F. W., Smith, J. S. and Dewey, P. J. S. The nutritive value for sheep of ruminant Diet AA6, a complete cobbed diet containing 30\% barley straw .

MACKenzie, A. J. and Edex, T. N. Short-term undernutrition and prenatal mortality in young and mature Merino ewes

Mackenzie, A. J. and Edey, T. N. Effects of pre-mating undernutrition on oestrus, ovulation and prenatal mortality in Merino ewes .

Macrae, J. C., Campbeld, D. R. and Eadie, J. Changes in the biochemical composition of herbage upon freezing and thawing

Srvarajasingam, S. and MukherJex, T. K. The results of the Red Sindhi grading-up scheme in Malaysia

$\mathrm{McR}_{\mathrm{AE}}, \mathrm{S}$. G. The presence of indigenous glauconite in soils and its effect on soil fertility. I. Soils developed on sandy drift (Barming series) . . . . . . . . . .

MoRAE, S. G. The presence of indigenous glauconite in soils and its effect on soil fertility. II. Soils developed on Gault Clay (Denchworth series) 
KaLLA, S. D. and Ghosh, P. K. Blood biochemical polymorphic traits in relation to wool production efficiency in Indian sheep .

ENGLAND, F. Heritabilities and genetic correlations for yield in Italian ryegrass (Lolium Multiflorum Lam.) grown at different densities

Bolton, J. Effects of sulphur fertilizers and of copper on the yield and composition of spring wheat grown in a sandy soil prone to surface compaction

NaKar, H. and Goto, M. An approach for breeding varieties of rice resistant to bacterial leaf blight with induced mutations

Broster, W. H., Broster, Valerie J., Smith, T. and Siviter, J. W. Experiments on the nutrition of the dairy heifer. IX. Food utilization in lactation

\section{SHORT Note}

Pushman, Frona M. The effects of alteration of grain moisture content by wetting or drying on the test weight of four winter wheats

\section{PART 2 (APRIL 1975)}

Perry, B. N. The incorporation of radioactively labelled amino acids into skeletal muscle protein by Pietrain and Large White pigs

Price, M. A. The effects of added dietary lipid on the body composition of rams and wethers

Park, R. J., Ford, Anne, Mrnson, D. J. and Baxter, R. I. Lucerne-derived flavour in sheep meat as affected by season and duration of grazing

Worker, G. F. Field crops and variety comparison between Imperial Valley, California and Kufra Oasis, Libya

Wood, J. D., Enser, M. B. and Restall, D. J. Fat cell size in Pietrain and Large White pigs

BaIRD, G. D. and Young, JANICE L. The response of key gluconeogenic enzymes in bovine liver to various dietary and hormonal regimes

Al-Nakshabandi, G. A. and Ismail, H. N. The transpiration of Mexipak wheat (Triticum aestivium $\mathrm{L}_{\text {.) }}$ in central Iraq .

Bassiri, A., RouHani, I. and GHorashy, S. R. Effect of temperature and scarification on germination and emergence of wild safflower, Carthamus oxyacantha Bieb . . .

Sykes, A. R. and Dingwall, R. A. Calcium absorption during lactation in sheep with demineralized skeletons

Suttle, N. F., Alloway, B. J. and Thornton, I. An effect of soil ingestion on the utilization of dietary copper by sheep

SUTTLE, N. F. Changes in the availability of dietary copper to young lambs associated with age and weaning

Ngere, L. O. and Dzakuma, J. M. The effect of sudden introduction of rams on oestrus pattern of tropical ewes

Davies, D. A. Productivity of S. 59 red fescue with and without S. 184 white clover under hill conditions. 1. Animal performance

Davies, D. A. Productivity of S. 59 red fescue with and without S. 184 white clover under hill conditions. 2. Herbage measurements in relation to animal performance 
L'Estrange, J. L. and MulvirmL, T. A. A survey of fat characteristics of lamb with particular reference to the soft fat condition in intensively fed lambs

Grbney, M. J. and L'Estrange, J. L. Effects of dietary unsaturated fat and of protein source on melting point and fatty acid composition of lamb fat

McKelvie, A. D., Olorunda, A. O. and KaY, M. The effect of Chlorpropham on the storage of swedes

Thomas, P. E. L. and Allison, J. C. S. Competition between maize and Rottboellia exaltata

Peart, J. N., Doney, J. M. and Macdonald, A. J. The influence of lamb genotype on the milk production of Blackface ewes

Sutton, J. D., Smith, R. H., McAllan, A. B., Storry, J. E. and Corse, D. A. Effect of variations in dietary protein and of supplements of cod-liver oil on energy digestion and microbial synthesis in the rumen of sheep fed hay and concentrates

Pendergrass, Ann, Gribert, M. D., Isenberg, F. M. R. and Lisk, D. J. Status of neodecanoic acids applied on onion (Allium cepa L.) foliage and phytotoxicity of neo-decanoic acids applied to organic soil .

Thomas, $\mathrm{H}$. The growth responses to weather of simulated vegetative swards of a single genotype of Lolium perenne .

RHODES, I. The relationship between productivity and some components of canopy structure in ryegrass (Lolium spp.). IV. Canopy characters and their relationship with sward yields in some intra population selections

Thomas, C., Wriknson, J. M. and Tayler, J. C. The utilization of maize silage for intensive beef production. I. The effect of level and source of supplementary nitrogen on the utilization of maize silage by cattle of different ages

Thomas, C., WILson, R. F., WiLkINs, R. J. and Wilkinson, J. M. The utilization of maize silage for intensive beef production. II. The effect of urea on silage fermentation and on the voluntary intake and performance of young cattle fed maize silage-based diets

Terry, R. A., Spooner, M. C. and Osbodrn, D. F. The feeding value of mixtures of alkalitreated straw and grass silage

SHORT NOTES

Wheeler, J. L., Hedges, D. A. and THL, A. R. A possible effect of cyanogenic glucoside in sorghum on animal requirements for sulphur

Hemmaway, R. G. and Fishwick, G. Defluorinated rock phosphate as a source of phosphorus for growing sheep

\section{Part 3 (June 1975)}

Aвoul-NaGA, A. M. Reproductive performance of Merino, sub-tropical Egyptian sheep and their crosses.

Fraser, D. and Morley Jones, R. The 'teat order' of suckling pigs. I. Relation to birth weight and subsequent growth

Fraser, D. The 'teat order' of suckling pigs. II. Fighting during suckling and the effects of clipping the eye teeth 
DerbyshiRe, Marjorie B. Skin follicle development in Cheviot $\times$ Dorset Horn cross foetuses

HEARN, A. B. Response of cotton to water and nitrogen in a tropical environment. I. Frequency of watering and method of application of nitrogen

Hearn, A. B. Response of cotton to water and nitrogen in a tropical environment. II. Date of last watering and rate of application of nitrogen fertilizer

WRIGHT, A. J. Methods of analysis of a competition diallel in Italian ryegrass with varying mixture proportions

Williams, Carolyn. The distribution of sulphur in the soils and herbage of North West Pembrokeshire

Ulyatt, M. J., Macrae, J. C., Clarke, R. T. J. and Pearce, P. D. Quantitative digestion of fresh herbage by sheep. IV. Protein synthesis in the stomach

Lerman, P. M. and BIE, S. W. Problems in determining the best levels of essential nutrients in feedingstuffs

Nikolić, J. Anna, Pavličević, A. and Zebrowska, Tereza. Quantitative and qualitative influences of dietary urea on the composition of duodenal digesta in calves .

Draycott, A. P., Durrant, M. J. and BennetT, S. N. Availability to arable crops of magnesium from kieserite and two forms of calcined magnesite .

Hopkins, G. J., Roberts, J. and Evans, J. V. Red Blood cell concentrations of reduced glutathione and potassium as biochemical markers of wool growth in Merino sheep .

Mendham, N. J. and Scott, R. K. The limiting effect of plant size at inflorescence initiation on subsequent growth and yield of oilseed rape (Brassica napus) .

ONwUEME, I. C. Influence of storage time on earliness of sprouting and tubering in Dioscorea rotundata yams

Keane, M. G. Effect of nutrition and dose level of PMS on oestrous response and ovulation rate in progestagen-treated non-cyclic Suffolk $\times$ Galway ewe lambs

Addiscott, T. M. and Johnston, A. E. Potassium in soils under different cropping systems. 3. Non-exchangeable potassium in soils from long-term experiments at Rothamsted and Woburn

Onwoeme, I. C. and Adegoroye, S. A. Emergence of seedlings from different depths following high temperature stress

HAGGAR, R. J. The effect of quantity, source and time of application of nitrogen fertilizers on the yield and quality of Andropogon gayanus at Shika, Nigeria

Ayoub, Aur T. Effect of some soil amendments on sodium uptake and translocation in dry beans ( $P$. vulgaris L.) in relation to sodium toxicity

Hornsey, K. G. The exploitation of polyploidy in sugar-beet breeding

Cummer, I. A., Blockey, M. A. de B., Winfield, C. G., Parr, R. A. and Wimliams, A. H. A study of relationships of breed, time of mating, level of nutrition, live weight, body condition, and face cover to embryo survival in ewes

\section{SHoRT Note}

Phipls, R. H. A note on the effect of genotype, density and row width on the yield and quality of forage maize

Butterworth, M. H., Diaz, J.A. and Hoystad, E. The use of carcass measurements to predict the yield of 'high-priced cuts' in carcass of Holstein calves . 
ONWUEME, I. C. and ADEGOROYE, S. A. Emergence of seedlings from different depths following high temperature stress

HAGGAR, R. J. The effect of quantity, source and time of application of nitrogen fertilizers on the yield and quality of Andropogon gayanus at Shika, Nigeria . . . . . .

AyOuB, Ali T. Effect of some soil amendments on sodium uptake and translocation in dry beans $(P$. vulgaris $L$.) in relation to sodium toxicity

HORNSEY, K. G. The exploitation of polyploidy in sugar-beet breeding 537

Cumming, I. A., Blockey, M. A. De B., Winfield, C. G., Parr, R. A. and Williams, A. H. A study of relationships of breed, time of mating, level of nutrition, live weight, body condition, and face cover to embryo survival in ewes

SHORT NOTES

PHIPPS, R. H. A note on the effect of genotype, density and row width on the yield and quality of forage maize

Butterworth, M. H., Diaz, J. A. and Hoystad, E. The use of carcass measurements to predict the yield of 'high-priced cuts' in carcass of Holstein calves . 


\section{THE JOURNAL OF AGRICULTURAL SCIENCE}

\section{CONTENTS}

\section{Vol. 84 Part 3 June 1975}

ABoul-NaGA, A. M. Reproductive performance of Merino, sub-tropical Egyptian sheep and their crosses

FRASER, D. and JONES, R. MORLEY. The 'teat order' of suckling pigs. I. Relation to birth weight and subsequent growth

FRASER, D. The 'teat order' of suckling pigs. II. Fighting during suckling and the effects of clipping the eye teeth

DERBYSHIRE, MARJORIE B. Skin follicle development in Cheviot $\times$ Dorset Horn cross foetuses

PAGE

HeARN, A. B. Response of cotton to water and nitrogen in a tropical environment. I. Frequency of watering and method of application of nitrogen

Hearn, A. B. Response of cotton to water and nitrogen in a tropical environment. II. Date of last watering and rate of application of nitrogen fertilizer

WRIGHT, A. J. Methods of analysis of a competition diallel in Italian ryegrass with varying mixture proportions.

Williams, Carolyn. The distribution of sulphur in the soils and herbage of North West

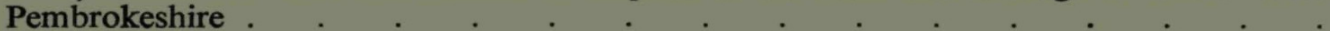

Ulyatt, M. J., Macrae, J. C., Clarke, R. T. J. and Pearce, P. D. Quantitative digestion of fresh herbage by sheep. IV. Protein synthesis in the stomach

Lerman, P. M. and BIE, S. W. Problems in determining the best levels of essential nutrients in feedingstuffs

Nikolić, J. Anna, Pavličević, A. and Zebrowska, Tereza. Quantitative and qualitative influences of dietary urea on the composition of duodenal digesta in calves

Draycott, A. P., Durrant, M. J. and BenNett, S. N. Availability to arable crops of magnesium from kieserite and two forms of calcined magnesite

Hopkins, G. J., Roberts, J. and Evans, J. V. Red blood cell concentrations of reduced glutathione and potassium as biochemical markers of wool growth in Merino sheep

Mendham, N. J. and Scotr, R. K. The limiting effect of plant size at inflorescence initiation on subsequent growth and yield of oilseed rape (Brassica napus)

ONwUEME, I. C. Influence of storage time on earliness of sprouting and tubering in Dioscorea rotundata yams

KEANE, M. G. Effect of nutrition and dose level of PMS on oestrous response and ovulation rate in progestagen-treated non-cyclic Suffolk $\times$ Galway ewe lambs.${ }^{\prime} \cdot{ }^{\prime} \cdot{ }^{\prime}$.

Addiscotr, T. M. and Johnston, A. E. Potassium in soils under different cropping systems. 3. Non-exchangeable potassium in soils from long-term experiments at Rothamsted and Woburn

Continued on inside back cover

(C) Cambridge University Press, 1975

SuBSCRIPTIONS. Two volumes of three parts are published annually. The 1975 subscription price is $£ 12.00$ net (U.S.A. and Canada US $\$ 38.50$ ) per volume (post free); single parts are available at $£ 5.00$ net (U.S.A. and Canada US $\$ 15.00$ ) plus postage. Orders or enquiries may be sent to any bookseller or subscription agent, or to Cambridge University Press, P.O. Box 92, London NW1 2DB (U.S.A. and Canada, Cambridge University Press, 32 East 57th Street, New York, N.Y. 10022. U.S.A.). 